\title{
Spectroscopic characterization of tungstated zirconia prepared by equilibrium adsorption from hydrogen peroxide solutions of tungsten(VI) precursors
}

\author{
Margarita Kantcheva - Cevryie Koz
}

Received: 19 July 2006/Accepted: 17 October 2006/Published online: 16 April 2007

(C) Springer Science+Business Media, LLC 2007

\begin{abstract}
Two series of $\mathrm{WO}_{x} / \mathrm{ZrO}_{2}$ samples are prepared by equilibrium adsorption from $\mathrm{H}_{2} \mathrm{O}_{2}$ solutions at $\mathrm{pH} 1.8$ containing two different precursor anions, $\left[\mathrm{W}_{2} \mathrm{O}_{3}\left(\mathrm{O}_{2}\right)_{4}\right.$ $\left.\left(\mathrm{H}_{2} \mathrm{O}\right)_{2}\right]^{2-}$ and $\left[\mathrm{H}_{2} \mathrm{~W}_{12} \mathrm{O}_{40}\right]^{6-}$. The starting material is amorphous zirconium oxyhydroxide. The maximum $\mathrm{W}$ densities obtained are larger than that reported in the literature for systems synthesized by the same method using aqueous non-peroxide solutions. In the case of the metatungstate precursor, this increase is attributed to the generation of additional anchoring sites by interaction between the amorphous support and $\mathrm{H}_{2} \mathrm{O}_{2}$. The high uptake achieved when the peroxo complex is used as a precursor is a result of both the $\mathrm{ZrO}_{x}(\mathrm{OH})_{4-2 x}-\mathrm{H}_{2} \mathrm{O}_{2}$ interaction and low nuclearity of the adsorbing anion. The materials are characterized by XRD, DR-UV-vis, Micro-Raman and FT-IR spectroscopy. The surface acidities of samples with identical $\mathrm{W}$ loading prepared by equilibrium adsorption from the $\left[\mathrm{H}_{2} \mathrm{~W}_{12} \mathrm{O}_{40}\right]^{6-}-\mathrm{H}_{2} \mathrm{O}_{2}$ system and by impregnation with aqueous solution of ammonium metatungstate are investigated by FT-IR spectroscopy of CO adsorbed at $80 \mathrm{~K}$.
\end{abstract}

\section{Introduction}

Among the zirconia-supported systems, tungsten oxidebased catalysts, have received a great deal of attention, because they are attractive as catalysts for the reactions of isomerization of light alkanes [1-7] and selective catalytic reduction of nitrogen oxides with hydrocarbons $[8,9]$. The

M. Kantcheva $(\bowtie) \cdot$ C. Koz

Laboratory for Advanced Functional materials, Department

of Chemistry, Bilkent University, 06800 Bilkent, Ankara,

Turkey

e-mail: margi@fen.bilkent.edu.tr catalytic properties of these oxide systems depend strongly on the $\mathrm{WO}_{x}$ surface density, which can be varied by changing the content of the active oxide phase and the catalyst treatment temperature [1-9].

The $\mathrm{WO}_{x} / \mathrm{ZrO}_{2}$ catalysts are usually prepared by impregnating hydrous zirconium oxyhydroxide, $\mathrm{ZrO}_{x}(\mathrm{OH})_{4-2 x}$, with aqueous solutions of ammonium metatungstate (AMT) [2-4, 6-13] or by coprecipitation [5] followed by calcination in air. In general, the equilibrium adsorption procedures allow better dispersion of the active phase and this method has been used by Valigi and coworkers [1316] to prepare various zirconia-based catalysts starting from amorphous $\mathrm{ZrO}_{x}(\mathrm{OH})_{4-2 x}$. These authors demonstrated the role of the solution $\mathrm{pH}$ in determining both the adsorption properties of the support and the predominant ionic form of the precursor. The latter is particularly important for tungsten, which can exist as monomeric species, $\left[\mathrm{WO}_{4}\right]^{2-}$, in solutions at $\mathrm{pH}$ higher than 8 , whereas oligomeric species, $\left[\mathrm{H}_{x} \mathrm{~W}_{y} \mathrm{O}_{z}\right]^{n-}$, are formed in acidic medium [17]. The adsorption of anionic species on zirconia is favored in solutions with a pH below 6.7 [18], the PZC of zirconia [14]. The large isopolyanions formed under these conditions suffer diffusion limitation into the micropores of the amorphous zirconium oxyhydroxide and can be adsorbed only on the external surface of the support grains [14]. Therefore, the application of anionic precursors with reduced nuclearity for synthesis of zirconiasupported $\mathrm{WO}_{\mathrm{x}}$ species can increase the ion-exchange capacity of the support and improve the dispersion of the adsorbed species. Low-condensed anionic oxoperoxometalate species can be generated dissolving metavanadates [19], polyoxomolybdates or -tungstates [20] in an excess of hydrogen peroxide at $\mathrm{pH} 0.5-2$. We used this experimental fact to develop a "peroxo route" for synthesis of $\mathrm{VO}_{x} /$ $\mathrm{ZrO}_{2}$ catalysts involving equilibrium adsorption of 
peroxovanadium(V) ions on stabilized zirconia in aqueous solutions at low $\mathrm{pH}$ [21]. Compared to the non-peroxide systems, the adsorption of vanadium( $\mathrm{V})$ peroxo ions resulted in approximately 2-fold increase of the loading and better dispersion of the $\mathrm{VO}_{x}$ species deposited on zirconia. Recently, Loridant et al. [22] used similar scheme in the preparation of tungstated zirconia by anionic exchange of peroxotungstate species with hydroxyl groups of $\mathrm{ZrO}_{x}(\mathrm{OH})_{4-2 x}$ at low $\mathrm{pH}$.

This paper presents a spectroscopic study of tungstated zirconias obtained by equilibrium adsorption using amorphous $\mathrm{ZrO}_{x}(\mathrm{OH})_{4-2 x}$ and aqueous solutions prepared by dissolving $\left(\mathrm{NH}_{4}\right)_{2} \mathrm{WO}_{4}$ and $\mathrm{AMT}$ in $\mathrm{H}_{2} \mathrm{O}_{2}$ as precursors. The structural characteristics of samples with identical tungsten loading obtained by the "peroxo route" and impregnation have been compared.

\section{Experimental}

\section{Sample Preparation}

Amorphous $\mathrm{ZrO}_{x}(\mathrm{OH})_{4-2 x}$ was prepared by hydrolysis of $\mathrm{ZrCl}_{4}$ (Merck, for synthesis) with concentrated (25\%) solution of ammonia as already described [23]. After washing (negative test for $\mathrm{Cl}^{-}$ions), the precipitate was dried at $383 \mathrm{~K}$ in air for $24 \mathrm{~h}$. According to XRD, the solid (specific surface area of $298 \mathrm{~m}^{2} / \mathrm{g}$ ) was amorphous. This material (denoted as $\mathrm{ZrO}_{2}-383$ ) was used to prepare the tungsten-containing samples. Two preparation procedures were employed:

(i) "Peroxo route" involving equilibrium adsorption from aqueous solutions prepared by dissolving two different $\mathrm{W}$-containing compounds in cold $30 \% \mathrm{H}_{2} \mathrm{O}_{2}$ (Merck, without stabilizers) at $\mathrm{pH}=1.8$ adjusted by addition of $\mathrm{HNO}_{3}$. The solutions with concentrations of $0.05,0.50$ and $0.75 \mathrm{~W} \mathrm{~mol} / \mathrm{L}$ containing the dimeric oxodiperoxo complex, $\left[\mathrm{W}_{2} \mathrm{O}_{3}\left(\mathrm{O}_{2}\right)_{4}\left(\mathrm{H}_{2} \mathrm{O}\right)_{2}\right]^{2-}$, were obtained using $\left(\mathrm{NH}_{4}\right)_{2} \mathrm{WO}_{4}$ (Aldrich) as a precursor [20]. These solutions were denoted as "solutions 1". The "solutions 2" with concentrations ranging from 0.05 to $0.90 \mathrm{~W} \mathrm{~mol} / \mathrm{L}$ were prepared by dissolving ammonium metatungstate $\left[\left(\mathrm{NH}_{4}\right)_{6} \mathrm{H}_{2} \mathrm{~W}_{12}\right.$ $\mathrm{O}_{40} \cdot 18 \mathrm{H}_{2} \mathrm{O}$, Fluka] (AMT). No precipitate formation from the precursor solutions 1 and 2 was observed within a period of $36 \mathrm{~h}$. The tungsten-containing samples were obtained by suspending an amount of $\mathrm{ZrO}_{2}-383$ in a large volume of the desired solution for $24 \mathrm{~h}$ upon stirring at room temperature. Then the solid was separated from the solution, washed several times with deionized water and dried at $383 \mathrm{~K}$ for $24 \mathrm{~h}$ followed by calcination for $4 \mathrm{~h}$ at $923 \mathrm{~K}$. The samples are designated as cWZ-1-T and cWZ-2-T, where 1 and 2 indicate the precursor solutions 1 and 2 , c stands for their concentration and $\mathrm{T}$ is the temperature of thermal treatment.

(ii) Impregnation: the sample was prepared by suspending for $24 \mathrm{~h} \mathrm{ZrO}_{2}-383$ in aqueous solutions containing an amount of AMT sufficient to obtain calcined material with loading of $19.0 \mathrm{wt} \% \mathrm{~W}$. Water was removed from the suspension by evaporation. The sample was submitted to the same thermal treatment as described above. The material obtained is denoted as WZ-I.

Characterization techniques

\section{Chemical analysis}

Tungsten in the as prepared samples (cWZ-1-383 and cWZ-2-383) was leached out in an excess of $2 \mathrm{M} \mathrm{NaOH}$. The calcined samples were fused with $\mathrm{KHSO}_{4}$ and then dissolved in water. The tungsten content was determined spectrophotometrically by the thiocyanate method [24, 25]. The $\mathrm{W}$ surface densities are expressed as the number of atoms per nanometer square of surface area $\left(\mathrm{W} / \mathrm{nm}^{2}\right)$.

\section{Surface area measurements, $X$-ray diffraction and DR- $U V$-vis spectroscopy}

The BET surface areas of the samples (dehydrated at $523 \mathrm{~K}$ ) were measured by nitrogen adsorption at $77 \mathrm{~K}$ using Monosorp apparatus from Quantachrome. XRD analysis was performed on a Rigaku Miniflex diffractometer with $\mathrm{Ni}$-filtered $\mathrm{Cu} \mathrm{K} \alpha$ radiation under ambient conditions. DR-UV-vis spectra were obtained under ambient conditions with a fiber optic spectrometer AvaSpec-2048 (Avantes) using WS-2 as a reference.

\section{Micro-Raman spectroscopy}

The micro-Raman spectra were recorded on a LabRam confocal Raman microscope with a $300 \mathrm{~mm}$ focal length. The spectrometer is equipped with a HeNe laser operated at $20 \mathrm{~mW}$, polarized 500:1 with a wavelength of $623.817 \mathrm{~nm}$, and $1024 \times 256$ element CCD camera. The signal collected was transmitted through a fiber optic cable into a grating with $600 \mathrm{~g} / \mathrm{mm}$ spectrometer.

\section{FT-IR spectroscopy}

The FT-IR spectra were recorded using a Bomem Hartman \& Braun MB-102 model FT-IR spectrometer with a liquidnitrogen cooled MCT detector at a resolution of $4 \mathrm{~cm}^{-1}$ 
(128 scans). The self-supporting discs $\left(0.035 \mathrm{~g} / \mathrm{cm}^{2}\right)$ were activated in the IR cell (Xenonum Scientific) equipped with a cryogenic apparatus by heating for $1 \mathrm{~h}$ in a vacuum at $723 \mathrm{~K}$, and in oxygen (100 mbar, passed through a trap cooled in liquid nitrogen) at the same temperature, followed by evacuation for $1 \mathrm{~h}$ at $723 \mathrm{~K}$. The CO $(99.95 \%$, BOC, passed through a trap cooled in liquid nitrogen) was introduced at $77 \mathrm{~K}$ in increasing amounts in the pressure range $0-25$ mbar.

\section{Results}

Tungsten species in the solutions

Figure 1a shows the Raman spectra of the prepared precursor solutions with concentrations of $0.50 \mathrm{~W} \mathrm{~mol} / \mathrm{L}$. The spectrum of the $\mathrm{H}_{2} \mathrm{O}_{2}$ solution (spectrum a) and that of non-peroxidic aqueous solution of AMT with concentration of $0.50 \mathrm{~W} \mathrm{~mol} / \mathrm{L}$ (spectrum d), both at $\mathrm{pH} \mathrm{1.8,} \mathrm{are} \mathrm{also}$ included. The strong band at $879 \mathrm{~cm}^{-1}$ in the former spectrum corresponds to the $\delta_{\mathrm{s}}(\mathrm{O}-\mathrm{O})$ mode of hydrogen peroxide [26] whereas the signal at $1050 \mathrm{~cm}^{-1}$ belongs to the $\mathrm{NO}_{3}^{-}$ion [27] from the $\mathrm{HNO}_{3}$ used for the $\mathrm{pH}$ adjustment. The observed Raman features of solution 1 (Fig. 1a, spectrum b) agree well with those of the $\left[\mathrm{W}_{2} \mathrm{O}_{3}\left(\mathrm{O}_{2}\right)_{4}\right.$ $\left.\left(\mathrm{H}_{2} \mathrm{O}\right)_{2}\right]^{2-}$ ion reported in the literature [28]. The band at $965 \mathrm{~cm}^{-1}$ corresponds to the $v(\mathrm{~W}=\mathrm{O})$ mode of the dimeric oxo-diperoxo species. The shoulder at $860 \mathrm{~cm}^{-1}$ of the strong Raman line at $873 \mathrm{~cm}^{-1}$ (due to the presence of excess $\left.\mathrm{H}_{2} \mathrm{O}_{2}\right)$ is characteristic of the $v(\mathrm{O}-\mathrm{O})$ vibration. The bands at 620 and $562 \mathrm{~cm}^{-1}$ are assigned to the $v_{\text {as }}\left[\mathrm{W}\left(\mathrm{O}_{2}\right)\right]$ and $v_{\mathrm{s}}\left[\mathrm{W}\left(\mathrm{O}_{2}\right)\right]$ modes, respectively. The signal at $325 \mathrm{~cm}^{-1}$ is characteristic of the $\mathrm{W}-\mathrm{OH}_{2}$ vibration. The band at $1050 \mathrm{~cm}^{-1}$ and the weak component at $720 \mathrm{~cm}^{-1}$ correspond to the $\mathrm{NO}_{3}^{-}$ions. The spectrum of solution 2 (Fig. 1a, spectrum c) is identical with that of the non-peroxide solution of AMT (Fig. 1a, spectrum d). The strong band at $879 \mathrm{~cm}^{-1}$ is due to the solvent $\mathrm{H}_{2} \mathrm{O}_{2}$. The signals at 979 , 968,945 and $898 \mathrm{~cm}^{-1}$ are characteristic of the metatungstate ion, $\left[\left(\mathrm{H}_{2}\right) \mathrm{W}_{12} \mathrm{O}_{40}\right]^{6-}[15]$. The spectral features of the AMT- $\mathrm{H}_{2} \mathrm{O}_{2}$ system do not change within a period of $24 \mathrm{~h}$. It can be concluded that under these conditions, the main tungsten species in solution 2 are the metatungstate ions and no $\mathrm{W}(\mathrm{VI})$ preoxo species are generated under these conditions. The spectra of the remaining $\mathrm{H}_{2} \mathrm{O}_{2}$ solutions of the starting tungsten compounds with concentrations different from $0.50 \mathrm{~W} \mathrm{~mol} / \mathrm{L}$ display the same Raman features as described above with band intensities varying with the concentrations.

Figure $1 \mathrm{~b}$ shows the Raman spectra of the peroxo solutions in contact with the hydrous zirconia after the equilibration for $24 \mathrm{~h}$. There are differences between the equilibrated and the starting solutions that need to be described. In the case of the equilibrated $\mathrm{ZrO}_{x}(\mathrm{OH})_{4-2 x}-\mathrm{H}_{2} \mathrm{O}_{2}$ system, the strong signal at $879 \mathrm{~cm}^{-1}$ is absent in the spectrum of the solution (compare spectra a and $\mathrm{a}^{\prime}$ in Fig. 1), which indicates complete decomposition of the $\mathrm{H}_{2} \mathrm{O}_{2}$. The Raman spectrum of the solution contains bands at 984,944 and $305 \mathrm{~cm}^{-1}$. This spectrum is very similar to the that of aqueous solution of $\mathrm{ZrO}\left(\mathrm{NO}_{3}\right)_{2}$ (not shown) which suggests that hydrated $\mathrm{ZrO}^{2+}$ ions are formed during
Fig. 1 Panel a: Raman spectra of solutions at $\mathrm{pH} 1.8$ of (a) 30 wt $\% \mathrm{H}_{2} \mathrm{O}_{2}$, (b) $0.50 \mathrm{M}$ $\left(\mathrm{NH}_{4}\right)_{2} \mathrm{WO}_{4}$ in $30 \mathrm{wt} \% \mathrm{H}_{2} \mathrm{O}_{2}$ (solution 1), (c) $0.50 \mathrm{~W} \mathrm{~mol} / \mathrm{L}$ of AMT in $30 \mathrm{wt} \% \mathrm{H}_{2} \mathrm{O}_{2}$ (solution 2), and (d) $0.50 \mathrm{~W}$ $\mathrm{mol} / \mathrm{L}$ of AMT in $\mathrm{H}_{2} \mathrm{O}$. Panel b: Raman spectra of filtrates obtained after $24 \mathrm{~h}$ of equilibration with $\mathrm{ZrO}_{x}(\mathrm{OH})_{4-2 x}$ at $\mathrm{pH}$ 1.8: (a') $30 \mathrm{wt} \% \mathrm{H}_{2} \mathrm{O}_{2}$, (b') $0.50 \mathrm{M}\left(\mathrm{NH}_{4}\right)_{2} \mathrm{WO}_{4}$ in 30 wt $\% \mathrm{H}_{2} \mathrm{O}_{2}$ (solution 1), (c') $0.50 \mathrm{~W} \mathrm{~mol} / \mathrm{L}$ of AMT in 30 wt $\% \mathrm{H}_{2} \mathrm{O}_{2}$ (solution 2). The $\mathrm{Y}$ scale of the plot in panel $\mathbf{b}$ is extended by a factor of 2 relative to that in panel a. The signal indicated by asterisk belongs to the Si substrate used to record the spectra

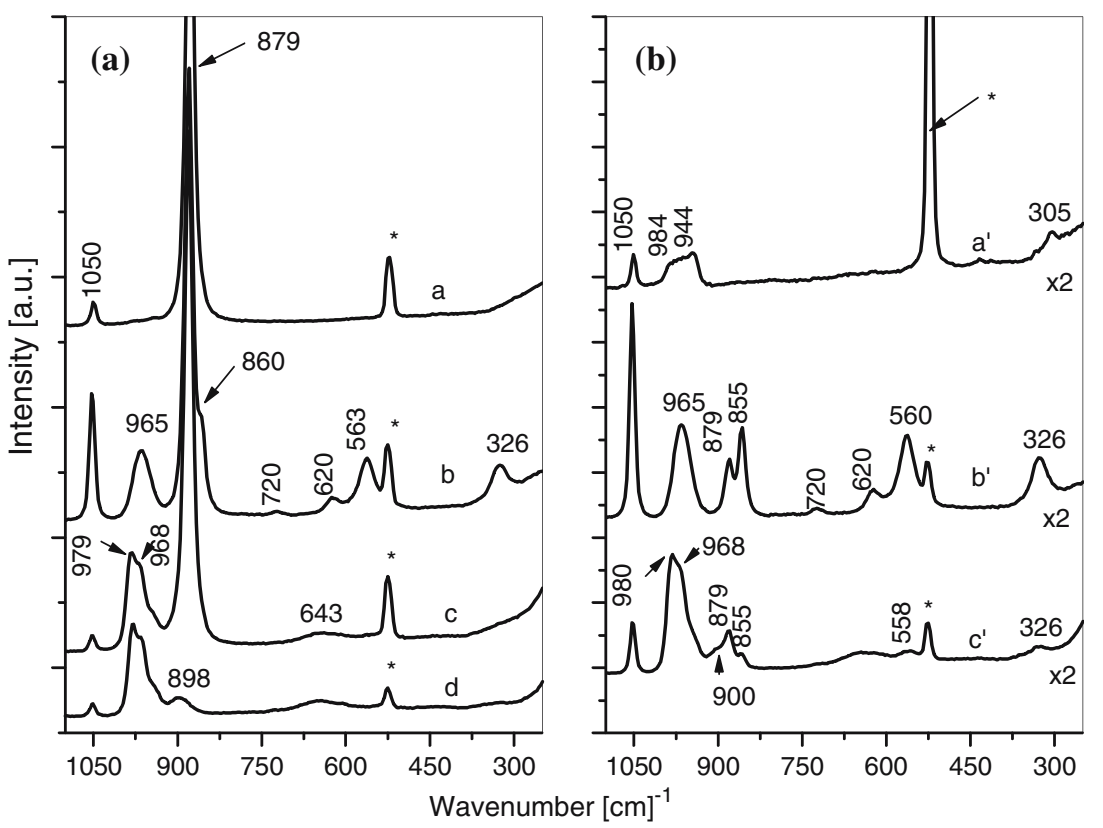


the interaction between the hydrous zirconia and $\mathrm{H}_{2} \mathrm{O}_{2}$. The presence of dissolved $\mathrm{Zr}^{4+}$ ions in the solution in equilibrium with the $\mathrm{ZrO}_{2}-383$ sample has been proven qualitatively by precipitation with $\mathrm{NH}_{3}$ solution. The Raman spectra of the equilibrated solutions 1 and 2 (Fig. 1b, spectra $b^{\prime}$ and $c^{\prime}$ ) show strong decrease in the intensity of the band at $879 \mathrm{~cm}^{-1}$ corresponding to the $v(\mathrm{O}-\mathrm{O})$ mode of the excess $\mathrm{H}_{2} \mathrm{O}_{2}$. This leads to the conclusion that compared to the $\mathrm{W}$-free solution in equilibrium with the $\mathrm{ZrO}_{2}$ 383 sample (Fig. 1b, spectrum a) the degradation of $\mathrm{H}_{2} \mathrm{O}_{2}$ in the presence of $\mathrm{W}(\mathrm{VI})$ anions occurs to a smaller extent. Most probably, the adsorbed tungsten species block some of the active sites of hydrous zirconia, which are involved in the $\mathrm{H}_{2} \mathrm{O}_{2}$ decomposition. The $\mathrm{ZrO}^{2+}$ ion cannot be detected under these conditions because its characteristic bands are covered by the strong signals of the $\mathrm{W}(\mathrm{VI})$ peroxo species and metatungstate ions. The traces $b^{\prime}$ and $c^{\prime}$ in Fig. 1b show that the intensities of the bands of the $\left[\mathrm{W}_{2} \mathrm{O}_{3}\left(\mathrm{O}_{2}\right)_{4}\left(\mathrm{H}_{2} \mathrm{O}\right)_{2}\right]^{2-}$ and metatungstate ions have decreased because of the ion exchange (compare with spectra $\mathrm{b}$ and $\mathrm{c}$ in Fig. 1a). The spectrum of the equilibrated solution 2 contains weak bands at 855,558 and $326 \mathrm{~cm}^{-1}$ characteristic of the $\left[\mathrm{W}_{2} \mathrm{O}_{3}\left(\mathrm{O}_{2}\right)_{4}\left(\mathrm{H}_{2} \mathrm{O}\right)_{2}\right]^{2-}$ ion [28] (see also spectra $b$ and $\left.b^{\prime}\right)$. Since no such signals are present in solution 2 before the contact with the hydrous zirconia (Fig. 1a, spectrum c), we can infer that the formation of $\mathrm{W}(\mathrm{VI})$ dimeric oxo-diperoxo complex from AMT is possible at a specific concentration ratio $\left[\mathrm{H}_{2} \mathrm{O}_{2}\right] /\left[\mathrm{W}^{6+}\right]$ different from that of the starting solution.

From these results, it can be concluded that the adsorbing species in solution 1 are the $\left[\mathrm{W}_{2} \mathrm{O}_{3}\left(\mathrm{O}_{2}\right)_{4}\right.$ $\left.\left(\mathrm{H}_{2} \mathrm{O}\right)_{2}\right]^{2-}$ ions, whereas the equilibrated solution 2 contains metatungstate ions as the major component and small amount of the $\left[\mathrm{W}_{2} \mathrm{O}_{3}\left(\mathrm{O}_{2}\right)_{4}\left(\mathrm{H}_{2} \mathrm{O}\right)_{2}\right]^{2-}$ species.

As prepared samples

\section{Tungsten uptake}

Figure 2 shows the variation of the $\mathrm{W}$ uptake and surface density as a function of the concentration of the precursor solutions expressed as $\mathrm{W} \mathrm{mol} / \mathrm{L}$. The $\mathrm{W}$ loading of the samples prepared from solutions 1 is higher than that of the samples obtained from solutions 2 (see also Table 1). Obviously, the uptake depends on the size of the adsorbing ions. In both cases, the uptake shows little dependence on the concentration of the precursor solutions and reaches a plateau for values larger than 0.50 and $0.75 \mathrm{~W} \mathrm{~mol} / \mathrm{L}$ for solutions 1 and 2, respectively. The surface densities were calculated based on the surface area of the $\mathrm{ZrO}_{2}-383$ support assuming that the latter was little affected by the $\mathrm{W}$ deposition. They lie in the range of 3.4-3.5 and 2.4-2.6 W/ $\mathrm{nm}^{2}$ for cWZ-1-383 and cWZ-2-383 samples, respectively.

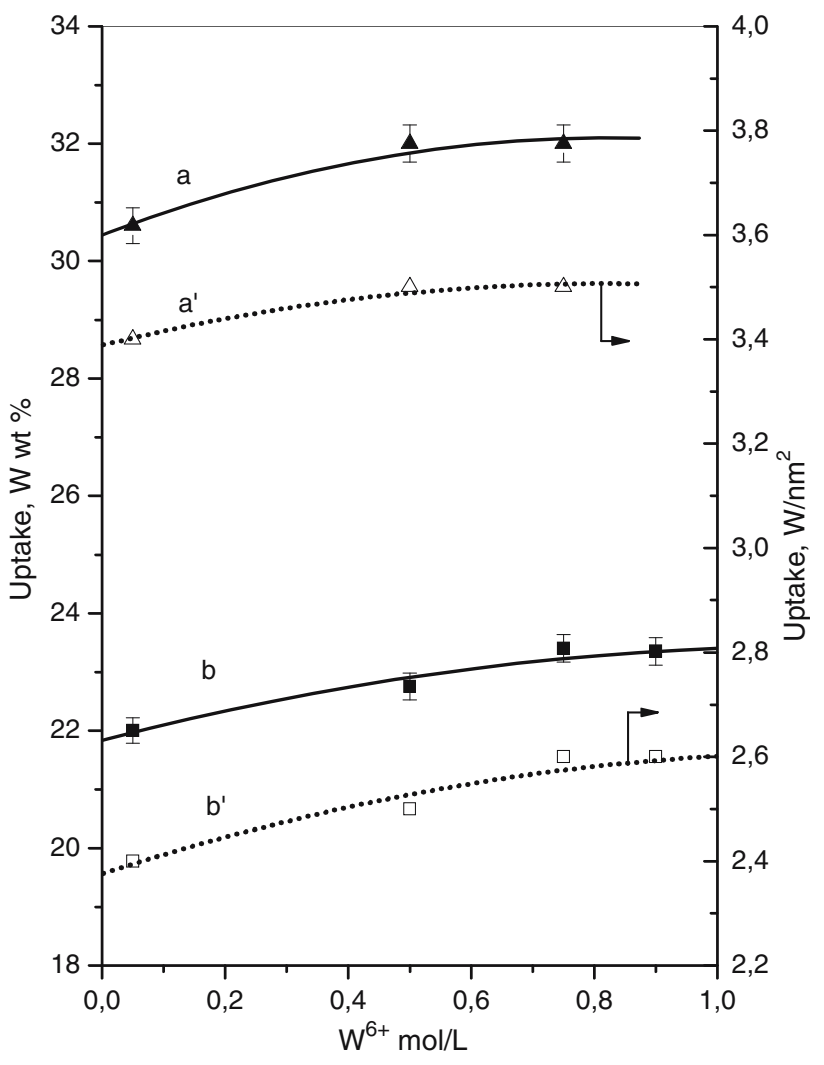

Fig. 2 Tungsten loading (wt $\%$ ) and surface concentration (W atoms/ $\mathrm{nm}^{2}$ ) of the as prepared samples as a function of the solution concentration (W mol/L): (a) and (a') samples cWZ-1-383; (b) and (b') samples cWZ-2-383

Table $1 \mathrm{~W}$ content, absorption edge position and number of nearest $\mathrm{W}$ atoms for the as prepared samples

\begin{tabular}{lllll}
\hline Sample & W wt\% & $\begin{array}{l}\text { Surface density } \\
\text { W/nm }\end{array}$ & $\mathrm{E}_{\text {edge }} \mathrm{eV}$ & $\mathrm{N}_{\mathrm{w}}$ \\
\hline $0.05 \mathrm{WZ}-1-383$ & 30.6 & 3.4 & 3.57 & 4.0 \\
$0.50 \mathrm{WZ}-1-383$ & 32.0 & 3.5 & 3.43 & 4.3 \\
$0.75 \mathrm{WZ}-1-383$ & 32.2 & 3.5 & 3.42 & 4.4 \\
$0.05 \mathrm{WZ}-2-383$ & 22.0 & 2.4 & 3.50 & 4.2 \\
$0.50 \mathrm{WZ}-2-383$ & 22.8 & 2.5 & 3.48 & 4.2 \\
$0.75 \mathrm{WZ}-2-383$ & 23.4 & 2.6 & 3.48 & 4.2 \\
$0.90 \mathrm{WZ}-2-383$ & 23.3 & 2.6 & 3.48 & 4.2 \\
\hline
\end{tabular}

\section{$D R-U V-v i s$ Spectroscopy}

The absorption spectra of the cWZ-383 samples are shown in Fig. 3. All samples exhibit absorption band at around 278-293 nm corresponding to charge-transfer (CT) transitions in W-O-W units of oligomeric tungstates $[3,4,10$, $12,29]$. The growth in intensity of this band (particularly for the cWZ-1-383) indicates increasing degree of condensation with increasing $\mathrm{W}$ loading. The absorption edge 
Fig. 3 DR-UV-vis spectra of the as prepared samples. Panel a: (a) 0.050WZ-1-383, (b) $0.50 \mathrm{WZ}-1-383$, and (c) 0.75WZ-1-383. Panel b: (a) 0.050WZ-2-383, (b) 0.50WZ-2383 , (c) $0.75 \mathrm{WZ}-2-383$ and (d) $0.90 \mathrm{WZ}-2-383$
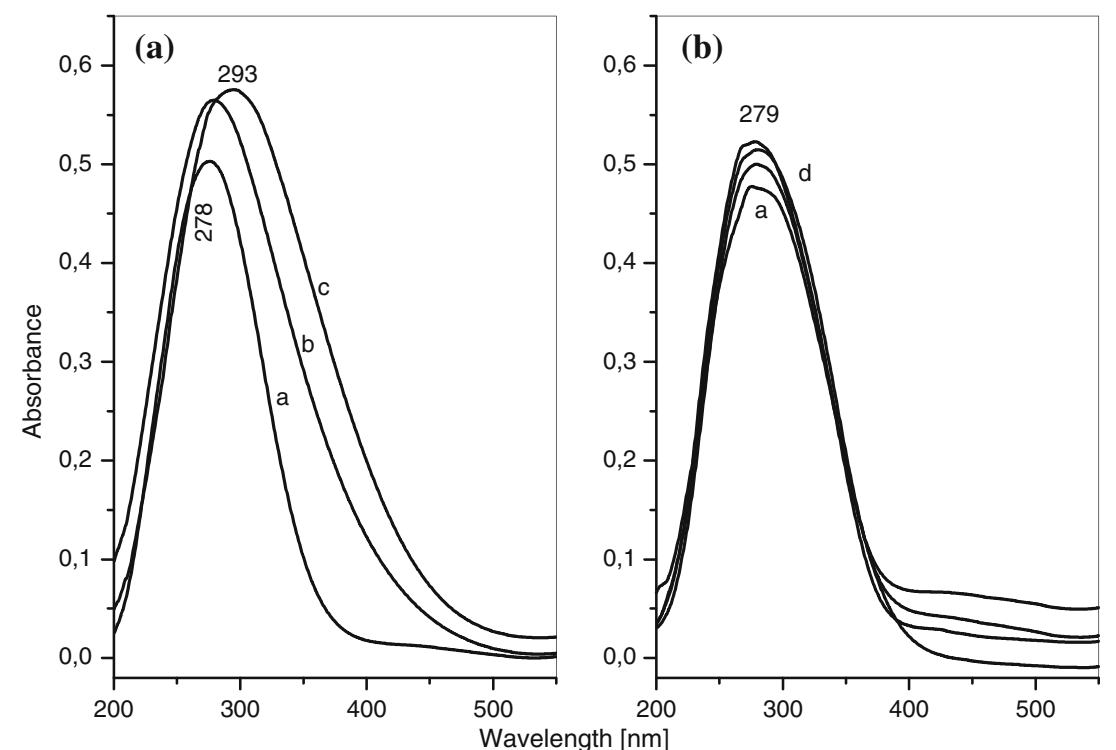

is clearly shifted towards higher wavelengths for samples 0.50WZ-1-383 and 0.75WZ-1-383 (Fig. 3a, spectra b and c) indicating presence probably of $\mathrm{WO}_{3}$. In contrast, the spectra of the samples of the cWZ-2-383 series (Fig. 3b) may reflect high dispersion of the $\mathrm{WO}_{x}$ species.

Weber [30] proposed an empirical linear correlation between the number of next nearest Mo neighbors $\left(\mathrm{N}_{\mathrm{Mo}}\right)$ for Mo-O compounds and supported $\mathrm{MoO}_{x}$ species and the value of the absorption edge energy $\left(\mathrm{E}_{\text {edge }}\right)$. Similar correlation between $\mathrm{N}_{\mathrm{W}}$ and $\mathrm{E}_{\text {edge }}$ was found for zirconiasupported $\mathrm{WO}_{x}$ species $[3,12]$. The absorption edge energy can be determined by a linear extrapolation to absorption equal zero in $(\alpha \mathrm{h} v)^{2}$ versus $\mathrm{h} v$ plots, where $\alpha$ is the absorbance and $\mathrm{h} v$ is the energy of the incident photon [3, $12,30]$. This method allows evaluating the average size of dispersed $\mathrm{WO}_{x}$ domains. Using the same reference values as Iglesia et al. $[3,12]$ we have calculated the $\mathrm{N}_{\mathrm{W}}$ values for the two sample series and the results are summarized in Table 1. The absorption edge energies of the cWZ-1-383 samples decrease increasing the loading. This indicates that average size of the $\mathrm{WO}_{x}$ clusters increases. In the case of the cWZ-2-383 samples, the absorption edge energy levels off for loading higher than $2.4 \mathrm{~W} / \mathrm{nm}^{2}$. The average size of the $\mathrm{WO}_{x}$ domains of the two sample series is comparable to that of AMT $\left(\mathrm{N}_{\mathrm{W}}=4[3,12]\right)$.

\section{Micro-Raman Spectroscopy}

The Raman spectrum (Fig. 4) of the amorphous zirconium oxyhydroxide (sample $\mathrm{ZrO}_{2}-383$ ) contains a broad band
Fig. 4 Raman spectra of the as prepared samples. Panel a: (a) $\mathrm{ZrO}_{2}-383$, (b) $\mathrm{ZrO}_{2}-383$ treated with $30 \mathrm{wt} \% \mathrm{H}_{2} \mathrm{O}_{2}$ for $24 \mathrm{~h}$, (c) 0.050WZ-1-383, (d) 0.50WZ-1383, and (e) 0.75WZ-1-383. Panel b: (a) $\mathrm{ZrO}_{2}-383$, (b) $\mathrm{ZrO}_{2}-$ 383 treated with $30 \mathrm{wt} \% \mathrm{H}_{2} \mathrm{O}_{2}$ for $24 \mathrm{~h}$, (c) $0.050 \mathrm{WZ}-2-383$, (d) $0.50 \mathrm{WZ}-2-383$, (e) $0.75 \mathrm{WZ}$ 2-383 and (f) 0.90WZ-2-383. The spectra are normalized to the band at $540 \mathrm{~cm}^{-1}$ of the $\mathrm{ZrO}_{2}-383$ sample

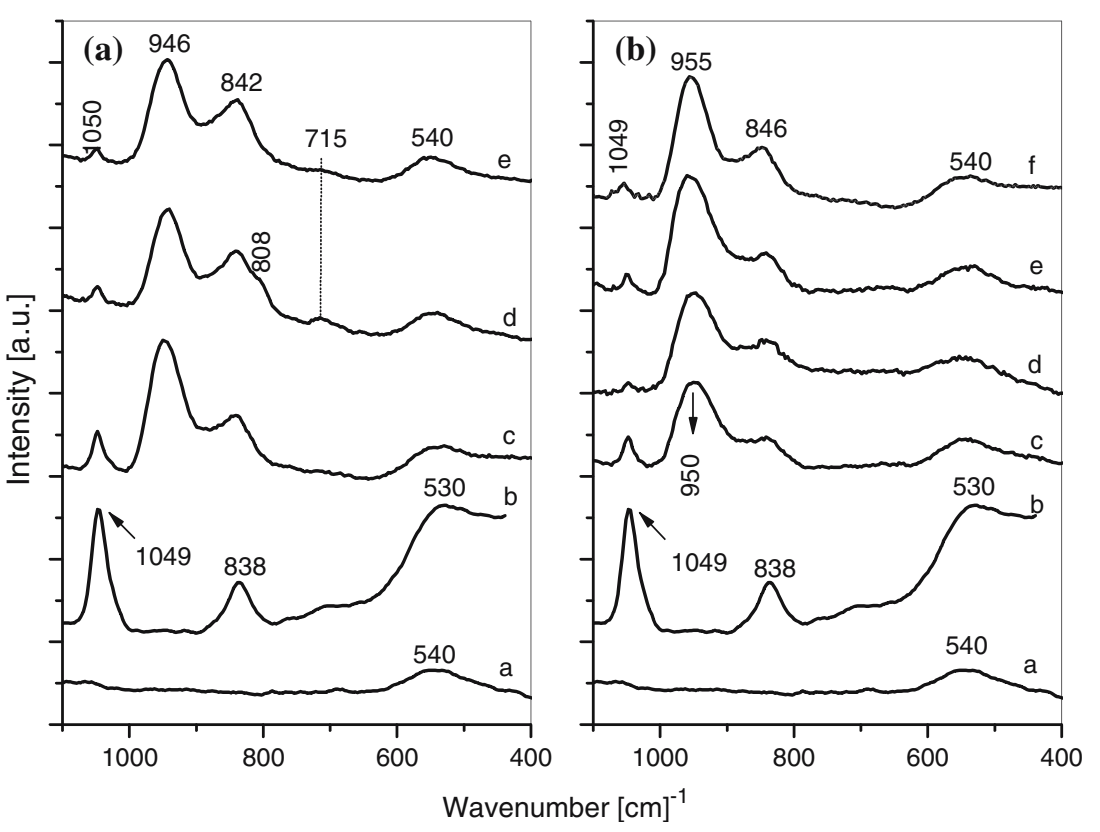


with maximum $540 \mathrm{~cm}^{-1}$, which is assigned to superimposed $\mathrm{Zr}-\mathrm{O}$ vibrations in ring structures and $\mathrm{Zr}-\mathrm{O}-\mathrm{Zr}$ bending mode between adjacent $\mathrm{ZrO}$ polyhedra [31]. Treatment of the $\mathrm{ZrO}_{2}-383$ sample with $30 \% \mathrm{H}_{2} \mathrm{O}_{2}$ for $24 \mathrm{~h}$ at $\mathrm{pH} 1.8$ causes the appearance of intense bands at 1049, 838 and $530 \mathrm{~cm}^{-1}$ (Fig. 4a and b, spectra a). The former band reveals presence of adsorbed $\mathrm{NO}_{3}^{-}$species [10]. The maximum at $838 \mathrm{~cm}^{-1}$ is characteristic of peroxo [ $v(\mathrm{O}-\mathrm{O})$ ] vibration and the broad, strong band at $530 \mathrm{~cm}^{-1}$ is attributed to the superimposed $v_{\text {as }}\left[\operatorname{Zr}\left(\mathrm{O}_{2}\right)\right]$ and $v_{\mathrm{s}}\left[\mathrm{Zr}\left(\mathrm{O}_{2}\right)\right]$ modes of peroxozirconium(IV) species, respectively [32]. Most probably, these species are formed on the amorphous zirconia as intermediates during the decomposition of $\mathrm{H}_{2} \mathrm{O}_{2}$.

Comparison of the Raman spectra of the cWZ-383 samples of the two series with that of the $\mathrm{H}_{2} \mathrm{O}_{2}$-treated $\mathrm{ZrO}_{2}-383$ (Fig. 4) shows strong decrease in the intensity of the band at $530 \mathrm{~cm}^{-1}$ relative to that at $842-846 \mathrm{~cm}^{-1}$. This suggests that the peroxozircinium(IV) species, if present, are formed in a smaller amount. It seems that the samples do not contain $\mathrm{W}(\mathrm{VI})$ peroxo species because the spectra do not show a signal at $560-620 \mathrm{~cm}^{-1}$ characteristic of the peroxo structural unit $\mathrm{W}\left(\mathrm{O}_{2}\right)$ [28]. The nitrate band is detected in the spectra of the samples of the two series being most intense on the materials prepared from the most diluted solutions (samples 0.05WZ-1-383 and 0.05WZ-2-383). This result indicates that a competitive adsorption between the $\mathrm{NO}_{3}^{-}$and the $\mathrm{W}$-containing species takes place.

The spectra of the cWZ-1-383 samples exhibit two maxima at 946 and $842 \mathrm{~cm}^{-1}$ (Fig. 4a). The former band is assigned to the $\mathrm{W}=\mathrm{O}$ stretching modes, whereas the band at $842 \mathrm{~cm}^{-1}$ is attributed to the W-O-W vibrations of hydrated oligomeric $\mathrm{WO}_{x}$ species $[10,11,13]$. This assignment is in agreement with the DR-UV-vis data according to which the average degree of aggregation of the $\mathrm{WO}_{x}$ clusters is close to that of AMT. The weak band at $715 \mathrm{~cm}^{-1}$ and the shoulder at $808 \mathrm{~cm}^{-1}$ in the spectrum of the sample 0.50WZ-1-383 reveal formation of some crystalline $\mathrm{WO}_{3}$
[10-12]. The latter compound is present also in the 0.75WZ-1-383 sample, which is evident by the appearance of a weak signal at $715 \mathrm{~cm}^{-1}$. The band profile of the samples of the cWZ-2-383 series (Fig. 4b) is similar to that of the cWZ-1-383 samples. The signal at $950 \mathrm{~cm}^{-1}$ in the spectrum of the $0.05 \mathrm{WZ}-2-383$ sample shifts slightly to a higher frequency as the $\mathrm{W}$ loading increases. No microcrystalline $\mathrm{WO}_{3}$ is detected in all cWZ-2-383 materials.

\section{Calcined samples}

\section{Physico-chemical characterization}

Table 2 summarizes the physico-chemical characteristics of the calcined samples. The tungsten loading of the as prepared and calcined samples is similar suggesting that the dried materials contain hydrated $\mathrm{WO}_{x}$ species $\left(\mathrm{WO}_{x} \cdot n \mathrm{H}_{2} \mathrm{O}\right)$. During the calcination, the loss of water from the latter partially offsets the weight loss of the amorphous zirconium oxyhydroxide. The sample prepared by impregnation has been also included in Table 2 to compare with the ion-exchanged materials. The surface areas of the zirconia-supported $\mathrm{WO}_{x}$ samples are larger than that of pure zirconia. The increase of the surface area after the deposition of $\mathrm{WO}_{x}$ species is well documented in the literature $[3,4,7,10,13]$. It is attributed to a reduction of the surface mobility of zirconia by the $\mathrm{WO}_{x}$ overlayer formed [10]. The surface areas of the cWZ-2-923 samples decrease as the loading exceeds $5.3 \mathrm{~W} / \mathrm{nm}^{2}$ but they remain higher than those of the cWZ-1-923 samples. The saturation limit for surface coverage with tungsten in dispersed form is estimated to be $\sim 4-6$ atoms $/ \mathrm{nm}^{2}[10,12,13,33$, 34]. It is apparent from Table 2 that the $\mathrm{W}$ surface densities of the cWZ-1-923 samples exceed this value, whereas the W surface densities for the 0.05WZ-2-923 and 0.50WZ-2923 samples lie in the saturation limit. The $\mathrm{W}$ loading of the impregnated WZ-I and 0.05WZ-2-923 samples is identical. However, the surface area of the former is considerably lower than that of the ion-exchanged material.
Table 2 Tungsten content and some characteristics of the samples calcined at $923 \mathrm{~K}$

$\mathrm{m}$ : monoclinic; t: tetragonal

\begin{tabular}{lccllll}
\hline Sample & W wt $\%$ & $\mathrm{~S}_{\mathrm{BET}} \mathrm{m}^{2} / \mathrm{g}$ & $\begin{array}{l}\text { Surface density } \\
\mathrm{W} / \mathrm{nm}^{2}\end{array}$ & $\mathrm{E}_{\text {edge }} \mathrm{eV}$ & $\mathrm{N}_{\mathrm{W}}$ & $\mathrm{XRD}$ \\
\hline $\mathrm{ZrO}_{2}-923$ & - & 56 & - & - & - & $\mathrm{m}-\mathrm{ZrO}_{2}$ \\
$0.05 \mathrm{WZ}-1-923$ & 30.1 & 114 & 8.6 & - & - & $\mathrm{t}-\mathrm{ZrO}_{2}+\mathrm{WO}_{3}$ \\
$0.50 \mathrm{WZ}-1-923$ & 31.8 & 102 & 10.2 & - & - & $\mathrm{t}-\mathrm{ZrO}_{2}+\mathrm{WO}_{3}$ \\
$0.75 \mathrm{WZ}-1-923$ & 31.6 & 99 & 10.4 & - & - & $\mathrm{t}-\mathrm{ZrO}_{2}+\mathrm{WO}_{3}$ \\
$0.05 \mathrm{WZ}-2-923$ & 21.7 & 141 & 5.0 & 3.32 & 4.6 & $\mathrm{t}-\mathrm{ZrO}_{2}$ \\
$0.50 \mathrm{WZ}-2-923$ & 22.5 & 140 & 5.3 & 3.32 & 4.6 & $\mathrm{t}-\mathrm{ZrO}_{2}$ \\
$0.75 W Z-2-923$ & 23.1 & 131 & 5.8 & 3.29 & 4.7 & $\mathrm{t}-\mathrm{ZrO}_{2}+\mathrm{WO}_{3}$ \\
$0.90 W Z-2-923$ & 22.9 & 129 & 5.8 & 3.30 & 4.6 & $\mathrm{t}-\mathrm{ZrO}_{2}+\mathrm{WO}_{3}$ \\
WZ-I & 19.0 & 127 & 4.9 & 3.33 & 4.6 & $\mathrm{t}-\mathrm{ZrO}_{2}$ \\
\hline
\end{tabular}


The X-ray diffraction patterns for the samples studied indicate that the incorporation of $\mathrm{WO}_{x}$ species stabilizes the tetragonal phase of zirconia. This result agrees with the observed effect of the surface $\mathrm{WO}_{x}$ compounds on the fraction of tetragonal phase [3-5, 7, 10, 13]. All cWZ-1923 samples contain crystalline $\mathrm{WO}_{3}$. This compound is detected also in the 0.75WZ-2-923 and 0.90WZ-2-923 samples.

The absorption edge energies of the cWZ-2-923 samples (Table 2) do not change considerably with increase in the surface density and remain higher than those measured for $\mathrm{WO}_{3}(2.59 \mathrm{eV}[3,12])$. Compared to the as prepared samples (Table 1), the sizes of the $\mathrm{WO}_{x}$ domains have increased after the crystallization of zirconia. Because all samples of the cWZ-923 series contain considerable amount of $\mathrm{WO}_{3}$ detectable by XRD, the determination of the absorption edge position is not reliable.

\section{Micro-Raman Spectroscopy}

The Raman spectra of the cWZ-1-923 samples (Fig. 5a) exhibit strong bands due to crystalline $\mathrm{WO}_{3}$ [10-12] at 809 and $718 \mathrm{~cm}^{-1}$. Bands attributed to the stretching mode of terminal $\mathrm{W}=\mathrm{O}$ bonds of the $\mathrm{WO}_{x}$ clusters are observed at $988 \mathrm{~cm}^{-1}[10,11,13]$. The peak at $650 \mathrm{~cm}^{-1}$ corresponds to the tetragonal zirconia [10]. This result indicates that $\mathrm{WO}_{3}$ and polymeric tungstate domains coexist on the surface of the cWZ-1-923 samples.

The Raman spectra of the ion-exchanged cWZ-2-923 samples (Fig. 5b) possess badly defined bands at 990 (shoulder), 955 and $850 \mathrm{~cm}^{-1}$. The former two bands are characteristic of $\mathrm{W}=\mathrm{O}$ stretching vibrations of $\mathrm{W}=\mathrm{O}$ groups within the $\mathrm{WO}_{x}$ clusters, whereas that at $850 \mathrm{~cm}^{-1}$ is attributed to the $v_{\text {as }}(\mathrm{W}-\mathrm{O}-\mathrm{W})$ mode $[10,11,13]$. The comparison with the spectra of the as prepared samples (Fig. 4b) shows that the intensities of the bands at $850 \mathrm{~cm}^{-1}$ have increased relative to those at $955 \mathrm{~cm}^{-1}$. This indicates that the crystallization of zirconia causes agglomeration of the $\mathrm{WO}_{x}$ clusters leading to increase in the number of $\mathrm{W}$ $\mathrm{O}-\mathrm{W}$ linkages. Since the spectra are recorded under ambient conditions, the adsorbed water causes broadening and low frequency shift of the $\mathrm{W}=\mathrm{O}$ band $[10,11]$. The large envelop with maximum at $955 \mathrm{~cm}^{-1}$ suggests the presence of various $\mathrm{WO}_{x}$ species with different degree of hydration. The shoulder at approximately $880 \mathrm{~cm}^{-1}$, observed in the spectrum of the WZ-I sample (Fig. 5b, spectrum d), is assigned by Scheithauer et al. [10] to the $\mathrm{W}-\mathrm{O}-\mathrm{Zr}$ stretching mode. This band is not resolved for the ion-exchanged cWZ-2-923 materials. No peaks characteristic of $\mathrm{WO}_{3}$ are detected for the samples with surface densities ranging from 4.9 to $5.3 \mathrm{~W}$ atoms $/ \mathrm{nm}^{2}$ (samples 0.05WZ-2-923, 0.50WZ-2-923 and WZ-I). However, formation of $\mathrm{WO}_{3}$ is observed in the $0.75 \mathrm{WZ}-2-923$ and 0.90WZ-2-923 (surface densities of $5.8 \mathrm{~W} / \mathrm{nm}^{2}$ ) which is concluded from the appearance of bands at 716 and $808 \mathrm{~cm}^{-1}$ (the spectrum of the $0.90 \mathrm{WZ}-2-923$ sample is identical to that of the $0.75 \mathrm{WZ}-2-923$ sample and it is not shown).

\section{In situ FT-IR spectroscopy}

This technique was used to characterize the structure of the dehydrated cWZ-2-923 materials. The FT-IR spectra of the samples show different patterns in the $v(\mathrm{OH})$ stretching region (Fig. 6a). The spectrum of the $0.05 \mathrm{WZ}-2-923$ sample (surface density of $5 \mathrm{~W} / \mathrm{nm}^{2}$ ) exhibits very strong
Fig. 5 Raman spectra of the calcined samples. Panel a: (a) 0.050WZ-1-923, (b) 0.50WZ-1923, and (c) 0.75WZ-1-923. Panel b: (a) 0.050WZ-2-923, (b) 0.50WZ-2-923, (c) 0.75WZ-2923 and (d) WZ-I. The spectra are normalized to the tetragonal zirconia band at $650 \mathrm{~cm}^{-1}$

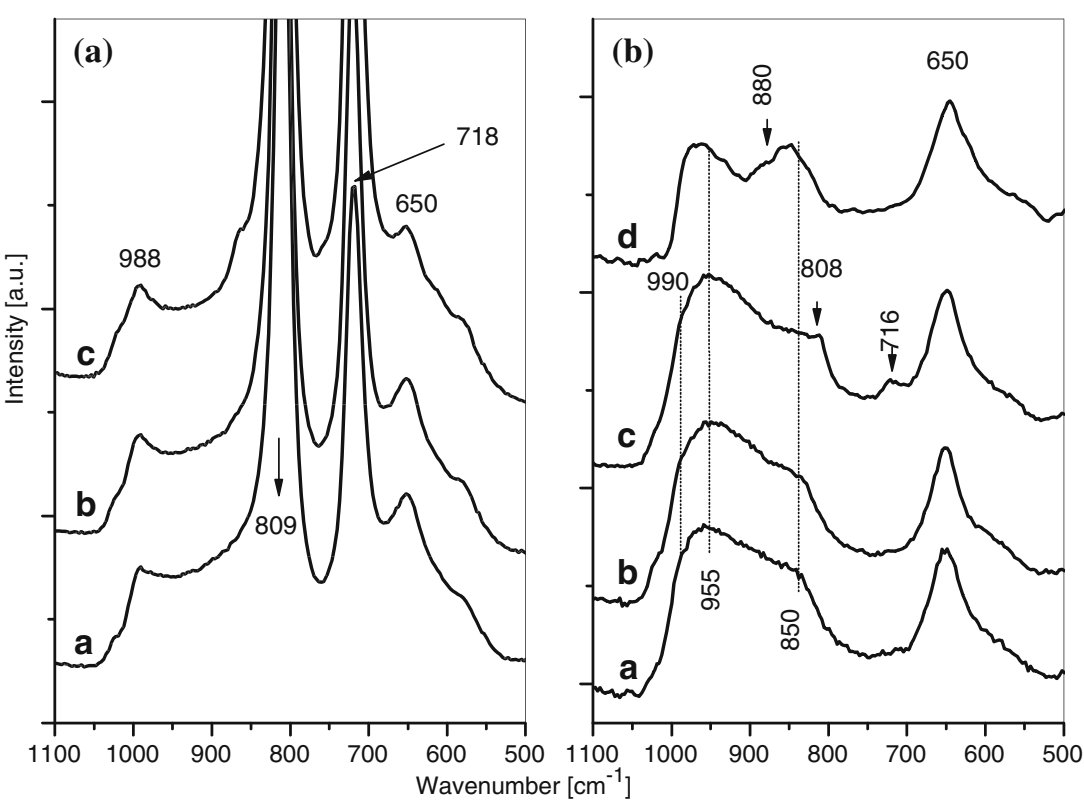


Fig. 6 FT-IR spectra in the $\mathrm{OH}$ stretching region (panel a), first $\mathrm{W}=\mathrm{O}$ overtone region (panel $\mathbf{b})$ and fundamental $\mathrm{W}=\mathrm{O}$ stretching region (panel c) of (a) 0.050WZ-2-923, (b) 0.50WZ-2923, (c) $0.75 \mathrm{WZ}-2-923$ and (d) WZ-I
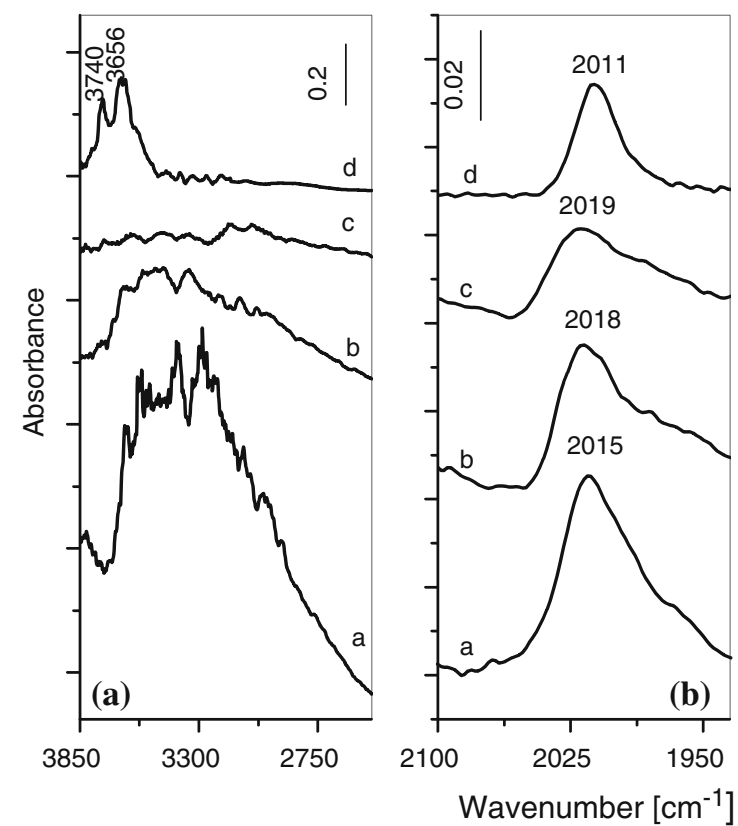

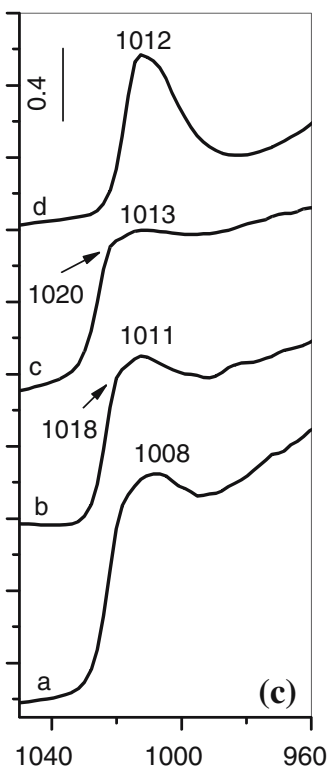

absorption between 3620 and $2600 \mathrm{~cm}^{-1}$. This indicates that this material is characterized by a high population of $\mathrm{W}-\mathrm{OH}$ groups $[6,10]$. No absorption corresponding to residual $\mathrm{OH}$ groups of zirconia is detected. The latter give rise to absorption bands above $3600 \mathrm{~cm}^{-1}$ [34-36] . At surface coverage of $5.3 \mathrm{~W} / \mathrm{nm}^{2}$ (sample $0.50 \mathrm{WZ}-2-923$, spectrum b) the intensity of the band in the $v(\mathrm{OH})$ stretching region decreases significantly and it becomes very weak in the spectrum of the $0.75 \mathrm{WZ}-2-923$ sample (Fig. 6a, spectrum c). The latter sample has the highest $\mathrm{W}$ loading $\left(5.8 \mathrm{~W} / \mathrm{nm}^{2}\right)$. The spectrum of the impregnated WZ-I material has two sharp bands at 3740 and $3652 \mathrm{~cm}^{-1}$ (Fig. 6a, spectrum d). The band at $3752 \mathrm{~cm}^{-1}$ is characteristic of the terminal $\mathrm{Zr}-\mathrm{OH}$ groups of tetragonal zirconia [35]. Based on the shift observed upon $\mathrm{CO}$ adsorption at $80 \mathrm{~K}$ (see below), the band at $3656 \mathrm{~cm}^{-1}$ is assigned to $\mathrm{W}-$ $\mathrm{OH}$ groups. The spectrum of the impregnated sample in the fundamental $\mathrm{W}=\mathrm{O}$ stretching region (Fig. 6c, spectrum d) shows a band at $1012 \mathrm{~cm}^{-1}$ which gives a single $\mathrm{W}=\mathrm{O}$ overtone vibration at $2012 \mathrm{~cm}^{-1}$. These are the typical spectral features corresponding to surface monoxo $\mathrm{W}=\mathrm{O}$ species $[10,37]$. The spectra of the dehydrated ion-exchanged samples in the $1050-950-\mathrm{cm}^{-1}$ region (Fig. 6c) have profiles that differ from that of the impregnated material and they show dependence on the tungsten loading. With increasing the surface density of $\mathrm{W}$, the maximum of the main band shifts to higher frequency with simultaneous decrease in the intensity. This indicates that progressive condensation of the $\mathrm{WO}_{x}$ domains takes place causing the decrease in the number of terminal $\mathrm{W}=\mathrm{O}$ species. A close inspection of the spectra shows that the
$\mathrm{W}=\mathrm{O}$ band of the ion-exchanged samples is split containing shoulders at $1018-1020 \mathrm{~cm}^{-1}$ and a wide and flat signal between ca. 1000 and $960 \mathrm{~cm}^{-1}$. Only the high-frequency components produce overtone bands at $2015-2019 \mathrm{~cm}^{-1}$. The latter vibrations display asymmetries toward lower frequencies. This and the fact that the absorption in the $1000-960 \mathrm{~cm}^{-1}$ region is absent in the spectrum of the impregnated sample may indicate that the adsorption of metatungstate ions in the presence of $\mathrm{H}_{2} \mathrm{O}_{2}$ results in a much broader distribution of various $\mathrm{WO}_{x}$ species having different $\mathrm{W}=\mathrm{O}$ bond orders. Two- and three-dimensional $\mathrm{WO}_{x}$ overlayers may coexist on the surface of zirconia as postulated by Scheithauer et al. [10] for high W loadings.

The intensities of the absorption in the $\mathrm{OH}$ region in the spectra of the ion-exchanged samples parallel the intensities of the $\mathrm{W}=\mathrm{O}$ bands. This indicates that the $\mathrm{OH}$ coverage of the activated samples is associated with hydroxyls produced by dissociative adsorption of ambient water on coordinatively unsaturated (cus) $\mathrm{W}=\mathrm{O}$ groups [38]. The $\mathrm{OH}$ groups complete the coordination sphere of the $\mathrm{W}=\mathrm{O}$ species and give rise to Brønsted acid sites [38]. Since the number of the cus $\mathrm{W}=\mathrm{O}$ species decreases with the increase in the $\mathrm{W}$ coverage, the amount of the $\mathrm{W}-\mathrm{OH}$ groups decreases as well.

Characterization of the acid sites of tungstated zirconia by FT-IR spectroscopy of adsorbed CO at low temperature

The 0.05WZ-2-923 and WZ-I samples have identical tungsten density. However, the FT-IR spectra show significant difference in their degree of hydroxylation. 
Furthermore, the spectra of these samples display different features in the $\mathrm{W}=\mathrm{O}$ fundamental and overtone region. Therefore, we studied the adsorption of $\mathrm{CO}$ at the temperature of liquid nitrogen, which is well known to characterize both Lewis and Brønsted acid sites on a solid surface. Three types of CO interactions with the surface of tungstated zirconia are reported to take place giving rise to absorption bands at ca. 2190, 2163-2164 and 2142$2143 \mathrm{~cm}^{-1}[6,10,34]$. They are characteristic of $\mathrm{CO}$ adsorbed on coordinatively unsaturated (cus) $\mathrm{Zr}^{4+}$ sites, Hbonding interactions with acidic hydroxyl groups and physisorbed CO, respectively. At $77 \mathrm{~K}, \mathrm{CO}$ is irreversibly bonded to the cus $\mathrm{Zr}^{4+}$ sites and the complex band at ca. $2190 \mathrm{~cm}^{-1}$ resists prolonged evacuation [34]. No evidence is found for $\mathrm{CO}$ bonded to cus $\mathrm{W}^{6+}$ species of tungstated zirconia $[6,10,34]$, which in the case of $\mathrm{WO}_{3} / \mathrm{SiO}_{2}$ [34] and $\mathrm{WO}_{3} / \mathrm{TiO}_{2}$ [39] are shown to give rise to carbonyl bands above $2200 \mathrm{~cm}^{-1}$.

Absorption bands similar to that reported in the literature $[6,10,34]$ are observed in the carbonyl region of the spectra of the 0.05WZ-2-923 and WZ-I samples obtained at $80 \mathrm{~K}$ upon introduction of incremental doses of $\mathrm{CO}$ (Fig. 7a, spectra 1a-1g and 2a-2d). On the 0.05WZ-2-923 sample, the $\mathrm{Zr}^{4+}-\mathrm{CO}$ bands are detected at 2191 and $2183 \mathrm{~cm}^{-1}$ after the admission of the first dose ensuring pressure of 0.05 mbar (Fig. 7a, spectrum 1a). These two bands become unresolved at $2190 \mathrm{~cm}^{-1}$ for higher $\mathrm{CO}$ pressures and saturate at 0.3 mbar (Fig. 7a, spectrum 1d). The growing signal at $2170 \mathrm{~cm}^{-1}$ indicates the interaction of $\mathrm{CO}$ with Brønsted acid sites. It broadens and shifts down to $2160 \mathrm{~cm}^{-1}$ at 8 -mbar saturation pressure of $\mathrm{CO}$ (the spectrum not shown). The low-frequency component at
$2144 \mathrm{~cm}^{-1}$ detected as a shoulder at higher pressures corresponds to a physisorbed $\mathrm{CO}[6,10,34]$. The spectrum in the $\mathrm{OH}$ region taken under equilibrium $\mathrm{CO}$ pressure of 2.5 mbar (Fig. 6b) shows the perturbation of the surface $\mathrm{W}-\mathrm{OH}$ hydroxyls. The adsorption of $\mathrm{CO}$ erodes the shoulder at ca. $3640 \mathrm{~cm}^{-1}$ and the maxima of the remaining bands shift to lower frequencies due to formation of $\mathrm{OH}-$ CO complexes [6, 10, 34].

The WZ-I sample contains also exposed $\mathrm{Zr}^{4+}$ ions giving rise at a low pressure of a carbonyl band at $2191 \mathrm{~cm}^{-1}$ (Fig. 7a, spectrum 2a). This band broadens and shits to lower frequency upon increasing doses of $\mathrm{CO}$ (Fig. 7a, spectra 2b-2f). Compared to the 0.05WZ-923 sample, the $\mathrm{Zr}^{4+}$-CO species require higher pressure of $\mathrm{CO}(0.6 \mathrm{mbar})$ to be saturated. The band corresponding to the $v(\mathrm{CO})$ stretching vibration of the $\mathrm{OH}-\mathrm{CO}$ complex initially observed at $2164 \mathrm{~cm}^{-1}$ (Fig. 7a, spectrum 2a) shifts to $2158 \mathrm{~cm}^{-1}$ after saturation at $5 \mathrm{mbar}$ of $\mathrm{CO}$ pressure. In the $v(\mathrm{OH})$ stretching region (Fig. 7b, spectra 2 and $2^{\prime}$ ), the adsorption of $\mathrm{CO}$ under these conditions induces shift of the band at $3740 \mathrm{~cm}^{-1}$ by ca. $20 \mathrm{~cm}^{-1}$ characteristic of the terminal hydroxyls of pure zirconia $[6,34,36]$. The relatively sharp band at $3660 \mathrm{~cm}^{-1}$ is no longer present and a broad absorption appears centered at approximately $3550 \mathrm{~cm}^{-1}$. The $\Delta v(\mathrm{OH})$ value is about $110 \mathrm{~cm}^{-1}$ and corresponds to the perturbation of acidic $\mathrm{W}-\mathrm{OH}$ groups caused by the weak base CO [6, 10].

For both samples the outgassing at the adsorption temperature (Fig. $7 \mathrm{a}$, spectra $1 \mathrm{~h}-1 \mathrm{j}$ and $2 \mathrm{~g}, 2 \mathrm{~h}$ ) causes disappearance of the $\mathrm{ZrOH}-\mathrm{CO}$ band and leaves the $\mathrm{Zr}^{4+}-\mathrm{CO}$ bands shifted to $2199 \mathrm{~cm}^{-1}$. The evacuation restores the original spectra in the $\mathrm{OH}$ stretching region.
Fig. 7 FT-IR spectra of CO adsorbed at $80 \mathrm{~K}$. Panel a: Spectra in the $v(\mathrm{CO})$ region of (1) sample 0.05WZ-2-923 upon increasing pressures of $\mathrm{CO}$ from (a) 0.05 mbar to (f) $0.6 \mathrm{mbar}$ and ( $h$ to $\mathrm{j}$ ) upon dynamic evacuation for a period of $30 \mathrm{~min}$, and (2) sample WZ-I upon increasing pressures of $\mathrm{CO}$ from (a) 0.10 mbar to (f) 5.0 mbar and $(\mathrm{g}, \mathrm{h})$ upon dynamic evacuation for a period of 30 min. Panel b: Spectra in the $v(\mathrm{OH})$ stretching region of (1) sample 0.05WZ-2-923 before $\mathrm{CO}$ adsorption and $\left(1^{\prime}\right)$ under 2.5 mbar CO, and (2) sample WZ-I before $\mathrm{CO}$ adsorption and (2') under 5 mbar $\mathrm{CO}$
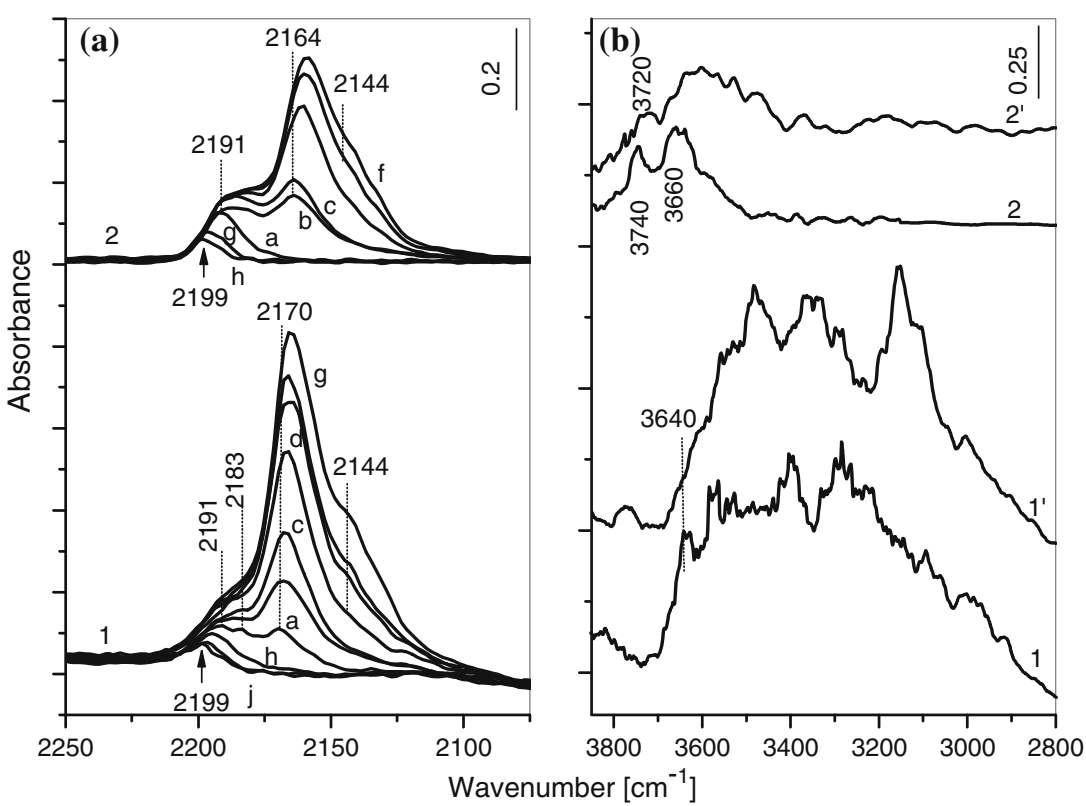


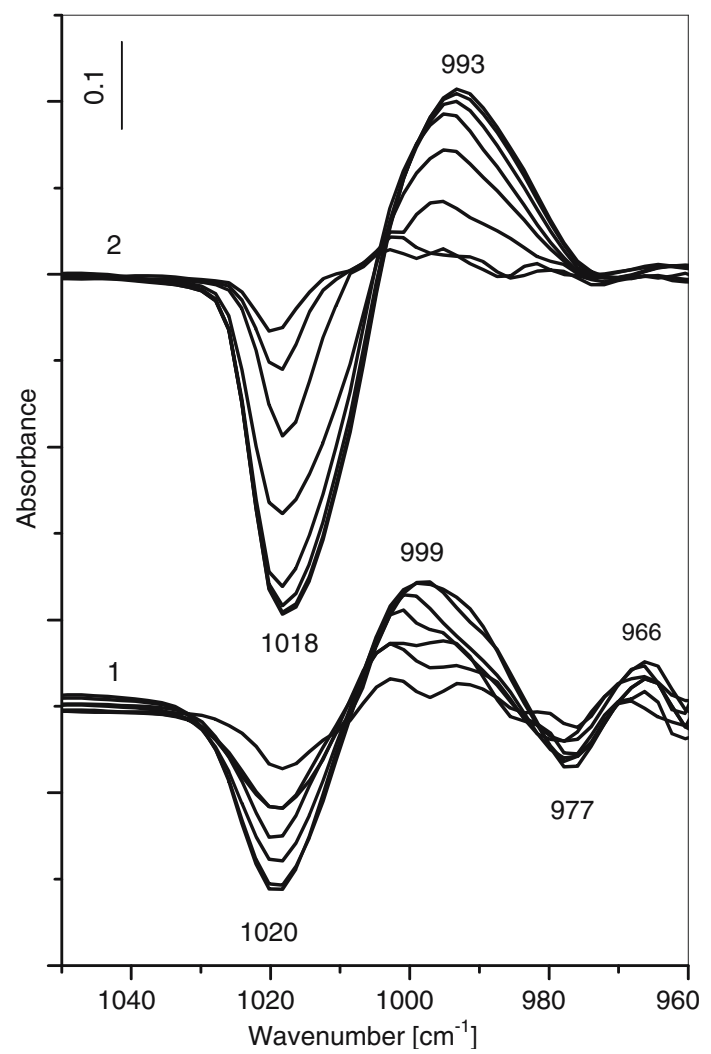

Fig. 8 Low-temperature FT-IR spectra in the $\mathrm{W}=\mathrm{O}$ stretching region after adsorption of increasing pressures of $\mathrm{CO}$ on (1) sample $0.05 \mathrm{WZ}$ 2-923 and (2) sample WZ-I. The spectra of the activated samples before the admission of $\mathrm{CO}$ are subtracted

Knözinger and coworkers $[6,10]$ have shown that the adsorption of $\mathrm{CO}$ on $\mathrm{Zr}^{4+}$ sites at $80-85 \mathrm{~K}$ affects the $\mathrm{W}=\mathrm{O}$ stretching modes of the neighboring polytungstate species. The latter vibration shifts to lower frequency due to inductive effects by the adsorbed CO. Figure 8 shows the
$977 \mathrm{~cm}^{-1}$ which shift to 999 and to $966 \mathrm{~cm}^{-1}$, respectively. On the WZ-I sample only one band at $1018 \mathrm{~cm}^{-1}$ is perturbed.

\section{Discussion}

The Raman spectra of the equilibrated solutions have shown that the adsorbing species in solution 1 are the $\left[\mathrm{W}_{2} \mathrm{O}_{3}\left(\mathrm{O}_{2}\right)_{4}\left(\mathrm{H}_{2} \mathrm{O}\right)_{2}\right]^{2-}$ ions. Although some amount of these ions has been formed in the equilibrated solution 2, the predominant species in this solution are the metatungstate ions, $\left[\mathrm{H}_{2} \mathrm{~W}_{12} \mathrm{O}_{40}\right]^{6-}$. Valigi et al. [14] concluded that the size of the metatungstate anion is comparable with the main micropore radius of amorphous zirconia. Because the size of the metatungstate ion is larger than that of the peroxo complex, limited adsorption from solution 2 occurs which lowers the uptake. The W surface densities in the as prepared samples using solutions 1 and 2 as precursors have been determined in the range of 3.4-3.5 and 2.4$2.6 \mathrm{~W} / \mathrm{nm}^{2}$, respectively. The latter value is higher than that reported in the literature $\left(0.4 \mathrm{~W} / \mathrm{nm}^{2}\right)$ for a system obtained by equilibrium adsorption from aqueous nonperoxide solutions at $\mathrm{pH} 2$ using hydrated zirconia as a starting material $[14,15]$.

Two main interactions between the surface of the amorphous zirconium oxyhydroxide and the anionic precursors at $\mathrm{pH} 1.8$ can be considered. The first interaction can be described mainly in terms of electrostatic attraction. It is known that in very acidic media (below the isoelectric point of zirconia), the hydroxyls of the support are protonated and they can act as anion adsorption sites [18]. This step for the $\left[\mathrm{W}_{2} \mathrm{O}_{3}\left(\mathrm{O}_{2}\right)_{4}\left(\mathrm{H}_{2} \mathrm{O}\right)_{2}\right]^{2-}$ precursor anion is schematically depicted below (Step 1):

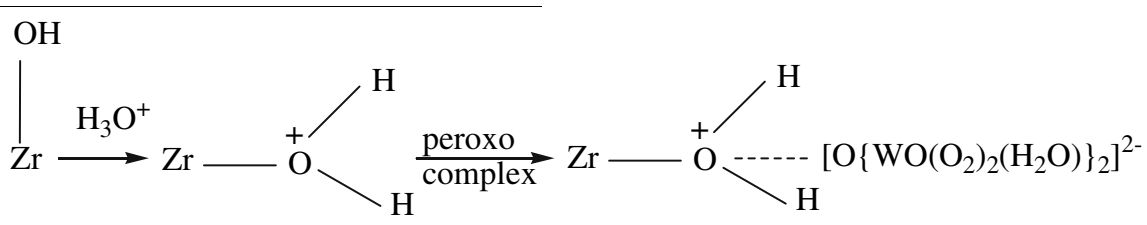

Step 1

perturbation of the $\mathrm{W}=\mathrm{O}$ stretching modes of the $0.05 \mathrm{WZ}$ 1-923 and WZ-I samples observed at $80 \mathrm{~K}$ upon increasing pressures of $\mathrm{CO}$. In the case of the ion-exchanged sample the adsorbed $\mathrm{CO}$ affects two $\mathrm{W}=\mathrm{O}$ bands at 1020 and
The second interaction involves a chemical reaction, which leads to increase in the amount of the protonated $\mathrm{OH}$ groups and to the formation of surface heteroperoxo complexes (Step 2): 


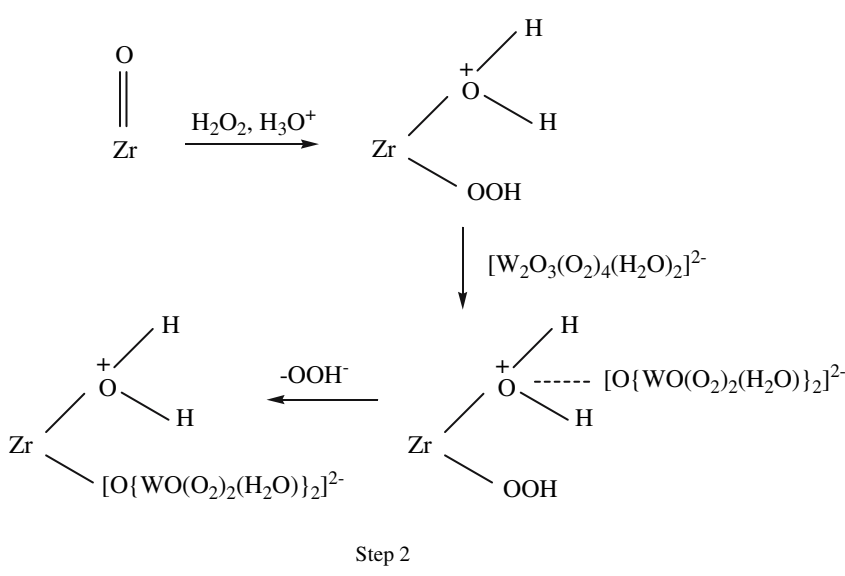

The generation of additional protonated hydroxyls combined with the reduced nuclearity of the precursor ions enhances the ion-exchanged capacity of the support.

Formation of surface $\mathrm{Zr}\left(\mathrm{O}_{2}\right)$ species is confirmed by the Raman spectrum of the $\mathrm{H}_{2} \mathrm{O}_{2}$-treated $\mathrm{ZrO}_{2}-383$ sample (Fig. 4). These species are stable and they are present on the sample dried at $383 \mathrm{~K}$. However, the $\mathrm{Zr}\left(\mathrm{O}_{2}\right)$ groups in the as prepared cWZ-1-383 samples are either absent or their amount is low. This suggests that the $\mathrm{Zr}(\mathrm{IV})$ peroxo species are replaced by the adsorbed $\left[\mathrm{W}_{2} \mathrm{O}_{3}\left(\mathrm{O}_{2}\right)_{4}\left(\mathrm{H}_{2} \mathrm{O}\right)_{2}\right]^{2-}$ ions. The latter most likely undergo degradation and rearrangement to polytungstates during the drying at $383 \mathrm{~K}$. The same adsorption scheme can be proposed for the metatungstate ions. However, the different types of the adsorbing anions present in solutions 1 and 2 establish different equilibria, which control the uptake.

Furthermore, the Raman data show presence of dissolved $\mathrm{Zr}^{4+}$ ions in the acidic $\mathrm{H}_{2} \mathrm{O}_{2}$ solution in equilibrium with the hydrous zirconia (Fig. 1b, spectrum a'). One may hypothesize that the partial solubility of the support can favor the formation of $\mathrm{Zr}$-containing polytungstates on the surface of the support. Carrier et al. [40] observed the formation of Anderson-type aluminum heteroplymolybdates on the surface of $\mathrm{MoO}_{x} / \gamma-\mathrm{Al}_{2} \mathrm{O}_{3}$ catalyst prepared by equilibrium adsorption from heptamolybdate solution. In the light of these considerations, the structure of the $\mathrm{WO}_{x}$ species of the cWZ-383 samples of the two series can be envisioned as $\mathrm{Zr}$-containing polytungstates as first proposed by Scheithauer et al. [10].

It can be concluded from the Raman spectra of the calcined samples that the deposition of $\mathrm{WO}_{x}$ species on zirconia by equilibrium adsorption from $\mathrm{H}_{2} \mathrm{O}_{2}$ solutions of $\left(\mathrm{NH}_{4}\right)_{2} \mathrm{WO}_{4}$ and $\mathrm{AMT}$ at $\mathrm{pH} 1.8$ gives better results for the metatungstate precursor. The $\mathrm{W}$ loading on the amorphous support that is achieved by adsorbing the dimeric oxo-diperoxo anion is high enough to exceed the monolayer capacity of zirconia after the crystallization. As a result, polytungstate domains coexist with crystalline $\mathrm{WO}_{3}$.
Loridant et al. [22] did not observe $\mathrm{WO}_{3}$ on their calcined samples prepared by ion exchange from the same peroxo precursor. The reason for this difference could be the short adsorption time employed in their synthesis (15 min).

According to the Raman spectra, the cWZ-2-923 samples with surface density of $5.0-5.3 \mathrm{~W} / \mathrm{nm}^{2}$ and the impregnated WZ-I material do not contain microcrystalline $\mathrm{WO}_{3}$. The FTIR spectra of $\mathrm{CO}$ adsorbed at $80 \mathrm{~K}$ indicate that the method of preparation (equilibrium adsorption versus impregnation) affects the extent of occupation of the Lewis acid sites of zirconia by the $\mathrm{WO}_{x}$ species and the amount and strength of the Brønsted acid sites. The 0.05WZ-2-923 and WZ-I samples have identical $\mathrm{W}$ density. However, the fact that the saturation of the $\mathrm{Zr}^{4+}$ ions of the 0.05WZ-2-923 sample by the adsorbed $\mathrm{CO}$ requires lower pressure suggests that the fraction of the $\mathrm{WO}_{x}$-free surface is lower in the ion-exchanged than in the impregnated material. On the other hand, the OH-CO band of the 0.05WZ-2-923 sample is at higher frequency and requires higher pressure of $\mathrm{CO}$ to be saturated than that of the WZ-I sample. This indicates $[6,10]$ that the amount and the strength of the Brønsted acid sites are higher on the ion-exchanged than on the impregnated material. According to the DR-UV-vis data, the average size of the $\mathrm{WO}_{x}$ domains on both samples is identical. However, the polytungstate overlayer on the ion-exchanged and impregnated samples may differ by the amount of $\mathrm{Zr}$-containing polytungstates. The fact that the spectra of the ion-exchanged cWZ-2-923 samples exhibit absorption in the 1000$960 \mathrm{~cm}^{-1}$ region (which is absent in the spectrum of the impregnated material) could support this assumption. This absorption may originate from $\mathrm{WO}_{x}$ clusters in which the $\mathrm{W}-$ O-Zr linkages to the support predominate. Eibl et al. [29] concluded that these species give rise to $\mathrm{W}=\mathrm{O}$ bands at low frequency. Recently, Carrier and co-workers [41, 42] suggested Lindqvist-type units, $\left[\mathrm{ZrW}_{5} \mathrm{O}_{18}\right]^{2-}$, as molecular analogues of zirconia-supported tungsten catalysts. The authors showed that the IR spectrum of the $\left[\mathrm{W}_{6} \mathrm{O}_{19}\right]^{2-}$ anion displays strong and symmetric $v_{\mathrm{s}}(\mathrm{W}=\mathrm{O})$ band at $996 \mathrm{~cm}^{-1}$. Substituting W with Zr causes this band to split and to shift to lower frequency $\left(972-965 \mathrm{~cm}^{-1}\right)$ [41, 42]. The FT-IR spectroscopic investigation of $\mathrm{CO}$ adsorbed at $80 \mathrm{~K}$ on the 0.05WZ-2-923 sample shows the perturbation of two bands at 1020 and $977 \mathrm{~cm}^{-1}$ after exposure to increasing pressures of the probe molecule, whereas only one band at $1018 \mathrm{~cm}^{-1}$ of the impregnated sample is affected by the adsorbed $\mathrm{CO}$ (Fig. 8). Therefore, we infer that the negative absorption at $977 \mathrm{~cm}^{-1}$ in Fig. 7 corresponds to the $\mathrm{W}=\mathrm{O}$ stretching modes of $\mathrm{Zr}$-containing polytungstates which are perturbed by the adsorbed CO. These heteropolytungstates (surface pseudohetropoly anions) proposed already by Scheithauer et al. [10] are responsible for the acidity of tungstated zirconia. Incorporation of $\mathrm{Zr}^{4+}$ ions into the $\left(\mathrm{WO}_{6}\right)_{x}$ network requires 
charge-compensation by protons generating permanent Brønsted acidity $[6,10]$. The formation of $\mathrm{Zr}$-containing polytungstates on the ion-exchanged sample is favored by the partial solubility of hydrous zirconia in the $\mathrm{H}_{2} \mathrm{O}_{2}$ solution. This probably occurs to a smaller extent in the course of impregnation of the support with an aqueous solution of AMT.

\section{Conclusions}

Two series of $\mathrm{WO}_{x} / \mathrm{ZrO}_{2}$ samples are prepared by equilibrium adsorption from $\mathrm{H}_{2} \mathrm{O}_{2}$ solutions at $\mathrm{pH} 1.8$ containing two different precursor anions, $\left[\mathrm{W}_{2} \mathrm{O}_{3}\left(\mathrm{O}_{2}\right)_{4}\left(\mathrm{H}_{2} \mathrm{O}\right)_{2}\right]^{2-}$ and $\left[\mathrm{H}_{2} \mathrm{~W}_{12} \mathrm{O}_{40}\right]^{6-}$. The starting material is amorphous zirconium oxyhydroxide. The maximum surface densities of the deposited $\mathrm{WO}_{x}$ species are larger than that reported in the literature for systems obtained by the same technique using aqueous non-peroxide solutions. In the case of the metatungstate precursor, this increase is attributed to the generation of large amount of protonated hydroxyls (acting as anchoring sites) by the interaction between the amorphous support and $\mathrm{H}_{2} \mathrm{O}_{2}$. For the peroxo complex, the increase in the uptake is associated with both the $\mathrm{ZrO}_{\mathrm{x}}(\mathrm{OH})_{4-2 x}-\mathrm{H}_{2} \mathrm{O}_{2}$ interaction and low nuclearity of the adsorbing anion.

The molecular structure of the materials is examined by DR-UV-vis, Micro-Raman and in situ FT-IR spectroscopy. The results are interpreted in terms of the increased polymerization of $\mathrm{WO}_{x}$ species with increasing the concentration of the precursor solutions, respectively the $\mathrm{W}$ loading. All materials obtained by adsorbing the $\left[\mathrm{W}_{2} \mathrm{O}_{3}\left(\mathrm{O}_{2}\right)_{4}\left(\mathrm{H}_{2} \mathrm{O}\right)_{2}\right]^{2-}$ ions contain crystalline $\mathrm{WO}_{3}$ after the calcination at $923 \mathrm{~K}$. In contrast, this compound does not form on the calcined samples with loading of $5.0-5.3 \mathrm{~W} / \mathrm{nm}^{2}$ prepared from the $\left[\mathrm{H}_{2} \mathrm{~W}_{12} \mathrm{O}_{40}\right]^{6-}-\mathrm{H}_{2} \mathrm{O}_{2}$ precursor solutions. The FT-IR spectra of $\mathrm{CO}$ adsorbed at $80 \mathrm{~K}$ indicate that the method of preparation (equilibrium adsorption from the $\left[\mathrm{H}_{2} \mathrm{~W}_{12} \mathrm{O}_{40}\right]^{6-}-\mathrm{H}_{2} \mathrm{O}_{2}$ system versus impregnation with aqueous solution of ammonium metatungstate) affects the extent of occupation of the Lewis acid sites of zirconia by the $\mathrm{WO}_{x}$ species and the amount and strength of the Brønsted acid sites. For materials with identical $\mathrm{W}$ loading, the fraction of the $\mathrm{WO}_{x}$-free surface is higher on the impregnated sample than that on the sample obtained by equilibrium adsorption from the $\left[\mathrm{H}_{2} \mathrm{~W}_{12} \mathrm{O}_{40}\right]^{6-}-\mathrm{H}_{2} \mathrm{O}_{2}$ solution. It is proposed that the high Brønsted acidity of the ion-exchanged sample is associated with the existence of a substantial amount of $\mathrm{Zr}$-containing polytungstates. Their formation is favored by the partial solubility of hydrous zirconia in the $\mathrm{H}_{2} \mathrm{O}_{2}$ solution.

Acknowledgements This work was financially supported by Bilkent University and the Scientific and Technical Research Council of Turkey (TÜBITAK), Projects 106T081 and 105M094.

\section{References}

1. Hino M, Arata K (1988) J Chem Soc Chem Commun 1259

2. Ono Y (2003) Catal Today $81: 3$

3. Iglesia E, Barton DG, Soled SL, MIESO S, Baumgartner JE, Gates WE, Fuentes GA, Meitzner GD (1996) In: Hightower JW, Delgass WN, Iglesia E, Bell AT (eds) Studies in surface science and catalysis, vol 101. Elsevier, Amsterdam, p 533

4. Barton DG, Soled SL, Meitzner DG, Fuentes GA, Iglesia EG (1999) J Catal 181:57

5. Santiesteban JG, Vartuli JC, Han S, Bastian D, Chang CD (1997) J Catal 168:431

6. Scheithauer M, Cheung T-K, Jentoft RE, Grasselli RG, Gates BC, Knözinger H (1998) J Catal 180:1

7. Kuba S, Lukinskas P, Grasselli RK, Gates BC, Knözinger H (2003) J Catal 216:353

8. Chin Y-H, Alvarez WE, Resasco DE (2000) Catal Today 62:159

9. Chin Y-H, Alvarez WE, Resasco DE (2000) Catal Today 62:291

10. Scheithauer M, Grasselli RK, Knözinger H (1998) Langmuir $14: 3019$

11. Kuba S, Concepcion Heydorn P, Grasselli RK, Gates BC, Che M, Knözinger H (2001) Phys Chem Chem Phys 3:146

12. Barton DG, Shtein M, Wilson RD, Soled SL, Iglesia E (1999) J Phys Chem B 103:630

13. Valigi M, Gazzoli D, Pettiti I, Matei G, Colonna S, De Rossi S, Ferraris G (2002) Appl Catal A 231:159

14. Valigi M, Gazzoli D, Cimino A, Proverbio E (1999) J Phys Chem B 103:11318

15. Gazzoli D, Valigi M, Dragone R, Marucci A, Mattei G (1997) J Phys Chem B 101:11129

16. Valigi M, Gazzoli D, Ferraris G, De Rossi S, Spinicci R (2005) Mol Catal A 227:59

17. Greenwood NN, Earnshaw A (2002) In: Chemistry of the elements. Butterworth \& Heineman, Oxford, p 1010

18. Brunelle JP (1978) J Pure Appl Chem 50:1211

19. Vol'nov I (1987) In: Peroxide complexes of vanadium, niobium and tantalum. Nauka, Moscow, p 12

20. Dickman MH, Pope MT (1994) Chem Rev 94:569

21. Kantcheva M (2000) Phys Chem Chem Phys 2:3043

22. Loridant S, Feche C, Essayem N, Figueras F (2005) J Phys Chem B 109:5631

23. Kantcheva M, Ciftlikli EZ (2002) J Phys Chem B 106:3941

24. Crouthamel CE, Johnson CE (1954) Anal Chem 26:1284

25. Wood DF, Clark RT (1958) Analyst 83:326

26. Nakamoto K (1997) In: Infrared and Raman spectra of inorganic and coordination compounds. Part A. J. Wiley \& Sons, New York, p 187

27. Nakamoto K (1997) In: Infrared and Raman spectra of inorganic and coordination compounds. Part A. J. Wiley \& Sons, New York, p 182

28. Aubry C, Chottard G, Platzer N, Brègeault J-M, Thouvenot R, Chauveau F, Huet C, Ledon H (1991) Inorg Chem 30:4409

29. Eibl S, Gates BC, Knözinger H (2001) Langmuir 17:107

30. Weber RS (1995) J Catal 151:470

31. Keramidas VG, White WB (1974) J Am Ceram Soc 57:22

32. Nakamoto K (1997) In: Infrared and Raman spectra of inorganic and coordination compounds. Part B. J. Wiley \& Sons, New York, p 157

33. Naito N, Katada N, Niwa M (1999) J Phys Chem B 103:7206

34. Ferraris G, De Rossi S, Gazzoli G, Pettiti I, Valigi M, Morterra C (2003) Appl Catal A 240:119

35. Jung KT, Bell AT (2000) J Molec Catal A 163:27

36. Hadjiivanov K, Lavalley J-C (2001) Catal Commun 2:129

37. Ramis G, Busca G, Cristiani C, Lietti L, Bregani F (1992) Langmuir 8:1744 
38. Busca G (2002) J Raman Spectrosc 33:348

39. Eibl S, Fentoft RE, Gates BC, Knözinger H (2000) Phys Chem Chem Phys 2:2565

40. Carrier X, Lambert JF, Che M (1997) J Am Chem Soc 119:10137
41. Villanneau R, Carabineiro H, Carrier X, Thouvenot R, Herson P, Lemos F, Ribeiro FR, Che M (2004) J Phys Chem B 108:12465

42. Carabineiro H, Villanneau R, Carrier X, Herson P, Lemos F, Ribeiro FR, Proust A, Che M (2006) Inorg Chem 45:1915 